\title{
PROBLEM OF DELAMINATION IN RC BEAMS STRENGTHENED BY FRP WITH RHEOLOGICAL MODEL OF ADHESIVE LEYER
}

\author{
Krzysztof KULA $^{1}$, Tomasz SOCHA ${ }^{2}$ \\ University of Zielona Gora, Zielona Góra, Poland
}

\begin{abstract}
This paper deals with one of the most dangerous failure modes in layered structures, namely delamination. The strengthening layer is modelled by a solid-shell finite element. The mechanical modelling of delamination onset and propagation is based upon a cohesive zone model implemented into a cohesive element located between adhesive layer and a concrete structure. The long time behavior of epoxy adhesive layer is modelled with the five-parameter rheological model.The numerical simulations are accomplished within the commercial software package Abaqus by the implementation of a user-written finite element and user-written material.
\end{abstract}

Keywords: delamination, FRP, concrete, cohesive element, solid-shell element, rhelogical model of epoxy

\section{INTRODUCTION}

Fibre reinforced polymers (FRP) have been used widely in the aerospace and automotive industry as a structural material for many years. Currently the material is also popular in civil engineering, especially as a strengthening layer. The properties of FRP make it very useful for increasing capacity of an existing

\footnotetext{
${ }^{1}$ Corresponding author: University of Zielona Gora, Faculty of Building, Architecture and Environmental Engineering, Z. Szafrana st 1, 65-516 Zielona Góra, Poland, e-mail: k.kula@ib.uz.zgora.pl, tel. +48683284788

2 Corresponding author: University of Zielona Gora, Faculty of Building, Architecture and Environmental Engineering, Z. Szafrana st 1, 65-516 Zielona Góra, Poland, e-mail: s.socha@ib.uz.zgora.pl, tel. +48683282271
} 
structure made of reinforced concrete (RC) or steel. The paper is focused on the $\mathrm{RC}$ beam retrofitted with FRP sheets. The reason of the strengthening is mostly partial degradation of a concrete girder and slabs. The bonding mechanism between RC and FRP is dependent on many factors e.g. the glue properties, surfaces preparation, components strength and stiffness. The bond complexity and the brittle fracture mechanism of the two components lead to many problems in estimation of the composite behaviour. The failure modes in the new structure are very complex, and some of them could be distinguished in each component e.g. cracks in concrete, tensile yielding of steel, rapture of FRP and debonding between components. The failure mode appeared between the components and is usually called delamination. The delamination is the one of dominant and the most dangerous mode failure in the layered composite structures. The failure relies on the discontinuity between adjoining layers and can lead to the loss of structural integrity. The reasons of delamination may be the geometrical discontinuities evoked by the state of stresses or material defects such as transversal concrete cracking. The efficient numerical tools which are able to predict and indicate the growth of delamination is the goal of mechanical sciences. The simulation of delamination in composite structures can be divided in two groups onset of delamination and delamination propagation, what is described in the part 3. The work in the part 2 treats about 3-D shell-solid finite element with the modification against locking effects. The element is used for modelling of the FRP layer. In the third part is presented the cohesive technique for the delamination simulation. Part 4 shows the mechanical models of concrete steel and the glue layer, where the five-parameter model is taken into acount. The calculation is realized by the commercial program Abaqus with user-written finite element. Some experimental results are taken from the literature e.g. [2,5,7,11] and utilized for comparison with the numerical results. The discussed numerical results are done with rheological model of adhesive layer and witout it.

\section{SOLID-SHELL ELEMENT}

The nonlinear analysis of the thin layers is accomplished by a solid-shell finite element. The basis of this finite element is the standard eight-node brick element with tri-linear shape functions. The element provides an accurate description of the interlaminar normal and shear stresses only for a very fine mesh in thickness direction of the composite structure. The pure displacement solid-shell element is improved by the assumed natural strain method (ANS) and the enhanced assumed strain method (EAS). The enrichments are necessary, since the pure element behaves too stiff and tends to locking. The ANS method being applied to transverse shear strains is able to reduce transverse shear locking [6,8]. To avoid the artificial thickness strains, i. e. curvature thickness locking, it is essential to 
use additionally a specific interpolation of thickness strains [5,7]. The volumetric locking and locking effects concerned with the membrane and bending behaviour are reduced by the EAS method which introduces additional enhanced strains into the finite element formulation [5,7]. Five strain parameters are utilized within the enhancement. The material of a typical layer is modelled by a hyperelastic orthotropic material formulation and is defined in a local material coordinate system. A suitable transformation matrix can be found e. g. in [5,7].

\section{DELAMINATION - NUMERICAL MODELLING}

In literature one can find several techniques for the prediction, i. e. the onset, and the propagation of cracks, see review $[1,6,9]$. The cohesive zone technique is one of them. It assumes a cohesive zone between two components RC and FRP in a composite structure. The cohesive layer has a very small but finite thickness relatively to the thickness of the FRP layer. The model relates stresses to relative displacements in the interface. This stress-separation model assumes initially a linear elastic behaviour of the interface followed by an initiation and an evolution of the failure. The used stress-separation-based model assumes three different types of separation well-known from the fracture mechanics, whereby one is normal to the interface (opening mode) and the two others are parallel to it (sliding or shearing modes). The failure initiation depends on the interfacial strength and can be estimated by a quadratic stress interaction function, originally proposed by Hashin [3]. This criterion can be represented as follows:

$$
\left(\frac{\left\langle\sigma_{33}\right\rangle}{R_{33}^{t}}\right)^{2}+\left(\frac{\sigma_{13}}{R_{13}}\right)^{2}+\left(\frac{\sigma_{23}}{R_{23}}\right)^{2} \leq 1
$$

where $\sigma_{33}$ is the interlaminar normal stress and $\sigma_{23}$ and $\sigma_{13}$ are the corresponding shear stresses in the interface. The stresses are calculated in integration points of a cohesive element. The Hashin criterion is presented in terms of Cauchy stresses. The quantities $R^{t}{ }_{33}, R_{23}$ and $R_{13}$ are the tensile strength in the thickness direction and the shear strengths, respectively. The symbol $\langle\bullet\rangle$ denotes the Macaulay

brackets $\left(\langle\bullet\rangle=\frac{1}{2}(|\bullet|+\bullet)\right)$. It means that only tensile stress $\sigma_{33}$ is included into Hashin criterion.

Interface damage evolution is expressed in terms of energy release $G$. The description of this model is available in the references $[1,6,10]$. In Figure 1 the relation is presented graphically. $\delta_{0}$ is the relative displacement corresponding to the strength $R$ in this direction (for one of the modes) and $\delta_{f}$ corresponds to the final displacement for separation. 


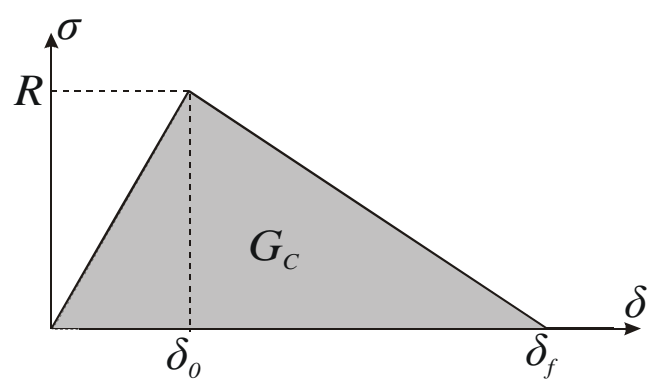

Fig. 1. Stress - relative displacement law

\section{CONCRETE, FRP, STEEL AND GLUE MODELS}

The concrete is modeled as the concrete damage plasticity material. The model is included into Abaqus and described in Abaqus documentation [1]. The model was previously formulated by Lubliner et. al. [1989] and developed by Lee and Fenves [1995]. The shape of the yield surface is assumed to remain constant and is defined by a modified Mohr-Coulomb criterion. The evolution of the elastic domain is defined by a hardening rule that is calibrated on the basis of experimental data. The plastic strain is defined on the basis of non-associated flow rule. The damage is assumed to be isotropic and is defined as a Young modulus reduction by a single scalar damage variable. The concrete damage plasticity model is in good agreement with experiments for prediction of cracks pattern in a concrete structure, also the RC strengthened by FRP [4].

The reinforcing steel is modeled as linear elastic-perfect plastic model. The FRP laminates is simulated as a linear elastic with rapture failure.

To describe the rheology glue one adopted five-parameter rheological model shown in Fig. 2. It is assumed that the CFRP band does not show rheological properties, which requires further study and confirmation.

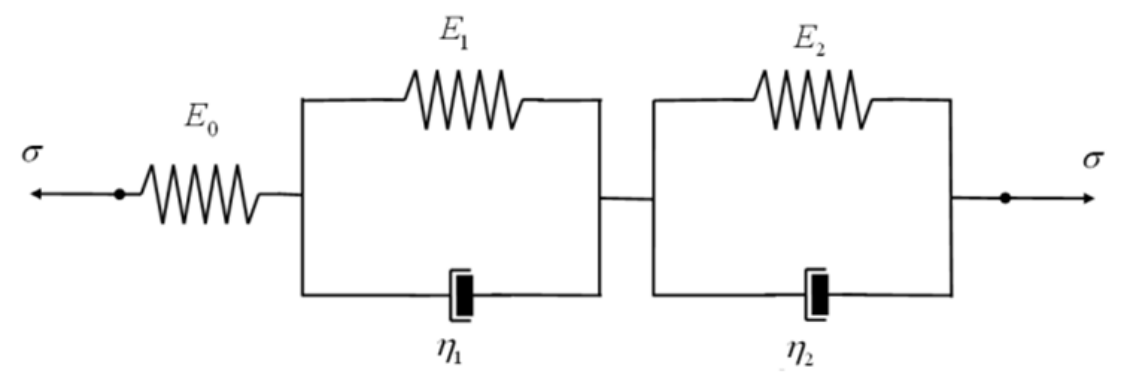

Fig. 2. Five-parameter rheological model 
Relaxation function takes the form of:

$$
\begin{aligned}
E(t)=\frac{1}{p_{2} \cdot \rho_{1} \cdot \rho_{2}} & \cdot\left\{q_{0}-\frac{1}{\rho_{2}-\rho_{1}} \cdot\left[\rho_{2} \cdot e^{\rho_{1} \cdot t} \cdot\left(q_{0}+q_{1} \cdot \rho_{1}+q_{2} \cdot \rho_{1}^{2}\right)-\right.\right. \\
& \left.\left.+\rho_{1} \cdot e^{\rho_{2} \cdot t} \cdot\left(q_{0}+q_{1} \cdot \rho_{2}+q_{2} \cdot \rho_{2}^{2}\right)\right]\right\}
\end{aligned}
$$

Where:

$$
\begin{gathered}
\rho_{1}=\frac{1}{2 \cdot p_{2}} \cdot\left[-p_{1}+\left(p_{1}^{2}-4 \cdot p_{2} \cdot p_{0}\right)^{\frac{1}{2}}\right] \\
\rho_{2}=\frac{1}{2 \cdot p_{2}} \cdot\left[-p_{1}-\left(p_{1}^{2}-4 \cdot p_{2} \cdot p_{0}\right)^{\frac{1}{2}}\right] \\
p_{0}=E_{0} \cdot E_{2}+E_{1} \cdot E_{2}+E_{0} \cdot E_{1}, p_{1}=\left(E_{0}+E_{1}\right) \cdot \eta_{2}+\left(E_{2}+E_{0}\right) \cdot \eta_{1}, \\
p_{2}=\eta_{1} \cdot \eta_{2}, q_{0}=E_{0} \cdot E_{1} \cdot E_{2}, q_{1}=E_{0} \cdot\left(E_{1} \cdot \eta_{2}+E_{2} \cdot \eta_{1}\right), \\
q_{2}=E_{0} \cdot \eta_{1} \cdot \eta_{2} .
\end{gathered}
$$

Parameter $E$ and $\eta$ of this model was calculated using the results of their research samples of these materials and the method of least squares. These issues will be developed in the work [9].

\section{NUMERICAL EXAMPLES}

The material parameters which are used in numerical calculation are taken from literature $[5,7,11]$ and the industry material specification.

Concrete

$E=26 \mathrm{GPa} ; \quad v=0.2 ; f_{c m}=20 \mathrm{MPa} ; f_{t m}=2 \mathrm{MPa}$.

FRP

$E=400 \mathrm{GPa} ; \quad v=0.25 ; f_{u}=1900 \mathrm{MPa}$.

Steel

$E=205 \mathrm{GPa} ; v=0.25 ; f_{d}=380 \mathrm{MPa}$.

Adhesive layer - glue

$E=2,5 \mathrm{GPa} ; v=0.25 ; R=4,5 \mathrm{MPa}$.

Cohesive zone

$R=4.5 \mathrm{MPa} ; G_{C}=0.85$. 


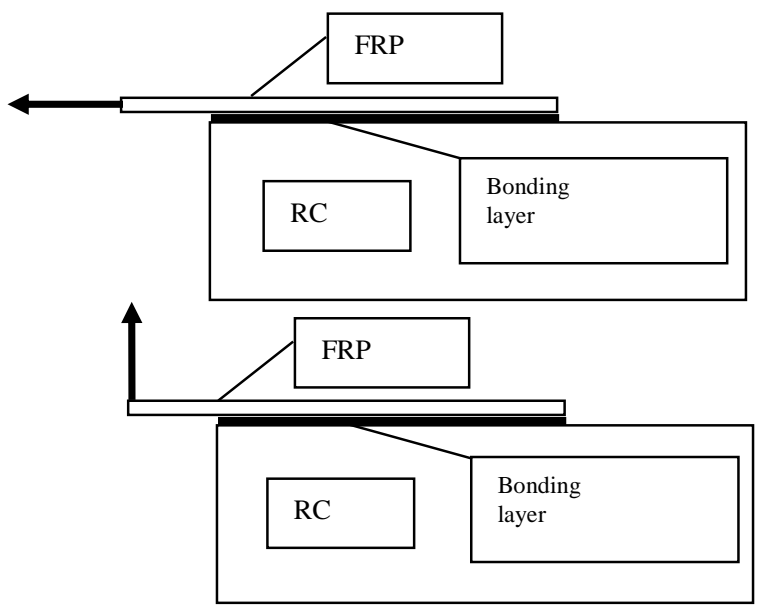

Fig. 3: Shear fracture mode (top) and peel fracture mode (bottom)

Fig. 3 illustrates a typical FRP bonded concrete models that are commonly used for an estimation of the parameters of cohesive zone and a verification of the FEM analysis results. The first results (the onset and growth of cracks in the bond layer) without rheological model of glue are in good agreement with the laboratory results taken from literature [7]. The result show that our model and user element are able to predict delamination and to simulate the progression of the phenomena. This work is focused on the influence of rheological behavior of the glue, the second numerical test estimated the change of displacement in the speciment after long time loading. The FE results done with Abaqus with user written material (five-parameter rheological model) show us the the growth of displacement $30 \%$ after 100 days in the shear test and $35 \%$ in the peel fracture mode test.

\section{CONCLUSIONS}

The five-parameter rheological model is used in the simulation of behavior of adhesive layer and it shows that the influence of long time loading is signifficiant. The discontinuity between the concret and FRP could appear in the bond layer without changing the load after long time of loading (the displacement growth after 100 days is $30-35 \%$ ). The further research will be focused on more complex tasks and on the correct estimation of glue properties, it is important for the coorect estimation of the structure behavior and design of strengthned structure. 


\section{REFERENCES}

1. ABAQUS Analysis User's Manual, 2010.

2. Choi, K.-K., Taha, M.M.R.: Rheological modeling and finite element simulation of epoxy adhesive creep in FRP-strengthened RC beams, Journal of Adhesion Science and Technology, 27 (2013), 1-13.

3. Hashin, Z.: Failure criteria for unidirectional composites, Journal for Applied Mechanics, 47(1980), 329-334.

4. Jankowiak, I.: Analysis of $R C$ beams strengthenedby CFRP stripsExperimental and FEA study, Archives of Civil and Mech. Engng, 12 (2012), 376-388.

5. Kotynia, R.: Bond between FRP and concrete in reinforced concrete beams strengthened with near surface mounted and externally bonded reinforcement, Construction and Building Materials, 32(2012), 41-54.

6. Kula, K., Schlebusch, R., Kuczma, M.: and Zastrau, B., On the delamination problem in fiber reinforced, Advances in the mechanics of inhomogeneous media, ed. by Cz. Woźniak, M. Kuczma, R. Świtka, K. Wilmański .- Zielona Góra 2010, 311-321.

7. Mazzoti, C., Savoia, M. and Ferracuti, B:, An experimental study on delamination of FRP plates bonded to concrete, Construction and Building Materials, 22(2008), 1409-1421.

8. Schlebusch R.: Theorie und Numerik einer oberflaechenorientierten Schalenformulierung (PhD thesis), Technische Universitaet Dresden, Dresden, 2005.

9. Socha T.: Ocena wpływu obciązeń dtugotrwatych na naprężenia $i$ odksztatcenia $w$ drewnianych belkach $z$ wklejonym zbrojeniem kompozytowym, Maszynopis rozprawy doktorskiej, Uniwersytet Zielonogórski 2005.

10. Turon, A.: Camanho, P. P., Costa, J. and Davila, C.G.: An interface damage model for the simulation of delamination under variablemode ratio in composite materials, NASA/TM-2004-213277, 2004.

11. Yao, J. and Teng, J.G., Plate end debonding in FRP-plated RC beams-I: Experiments, Engineering Structures, 29, pp. 2457-2471, 2007.

\section{PROBLEM DELAMINACJI W KONSTRUKCJACH ŻELBETOWYCH WZMACNIANYCH TAŚMAMI KOMPOZYTOWYMI Z UWZGLĘDNIENIEM REOLOGII KLEJU}

Streszczenie

W artykule zaprezentowano jeden $\mathrm{z}$ najbardziej niebezpiecznych mechanizmów zniszczenia konstrukcji warstwowych czyli delaminację. Belkę żelbetową wzmocnioną 
doklejoną taśmą kompozytową rozpatrzono jako układ warstwowy z uwzględnieniem reologii środkowej warstwy czyli spoiny klejowej. Warstwę tę modelowano numerycznie powłokowymi elementami skończonymi. Teoretyczny model powstawania delaminacji i jej propagacji jest oparty o strefę kohezyjną zaimplemnetowaną w elemencie kohezyjnym umieszczonym pomiędzy warstwą kleju a belką żelbetową. Reologiczne własności kleju epoksydowego opisano przy pomocy modelu pięcioparametrowego. Symulacje numeryczne przygotowano wykorzystując komercyjne oprogramowanie metody elementów skończonych ABAQUS oraz samodzielnie napisany $\mathrm{w}$ języku FORTRAN element skończony i materiał reologiczny. Uzyskane wyniki wskazują na znaczący wpływ obciążeń długotrwałych i zjawisk reologicznych na pracę belki żelbetowej wzmocnionej doklejoną taśmą kompozytową.

Słowa kluczowe: ABAQUS, CFRP, beton, stal, kompozyty, konstrukcje warstwowe, MES, pełzanie, reologia, wzmacnianie

Editor received the manuscript: 15.10 .2016 